threshold logic 



\section{SZE-TSEN HU}

threshold logic

UNIVERSITY OF CALIFORNIA PRESS

BERKELEY AND LOS ANGELES 1965 
University of California Press Berkeley and Los Angeles, California

Cambridge University Press London, England

(1) 1965 by The Regents of the University of California

Library of Congress Catalog Card Number: 65-21982

Designed by Geoffrey Ashton

Manufactured in the United States of America 